\title{
SISTEM PEMILIHAN DOSEN PEMBIMBING SKRIPSI DENGAN METODE TOPSIS (STUDI KASUS: PENDIDIKAN TEKNIK INFORMATIKA)
}

\author{
Tantri Hari Mukti ${ }^{1 \star}$, Syaad Patmantara ${ }^{2}$, dan Aji Prasetya Wibawa ${ }^{3}$ \\ 1,2,3 Teknik Elektro, Universitas Negeri Malang \\ Jl. Semarang No.5, Sumbersari, Kec. Lowokwaru, Kota Malang, Jawa Timur 65145 \\ "E-mail: tantri.mukti@gmail.com
}

\begin{abstract}
Abstrak
Penunjukan pembimbing skripsi di Program Studi Pendidikan Teknik Informatika Universitas Negeri Malang ditangani oleh tim dosen KBK (Kelompok Bidang Keahlian) dan dosen Koordinator Program Studi (Korprodi). Tim KBK dan Korprodi harus menyesuaikan kriteria-kriteria calon dosen pembimbing yang sesuai dengan kondisi dan judul yang diajukan mahasiswa. Selain itu Tim KBK dan Korprodi membutuhkan waktu yang lama untuk menyelesaikan banyaknya antrian pengajuan dosen pembimbing. Dari permasalahan tersebut, dibuat sistem yang dapat memberikan rekomendasi dosen pembimbing dengan menggunakan metode TOPSIS. Sehingga sistem tersebut dapat mempermudah tugas dosen KBK dan Korprodi. Pemilihan metode TOPSIS (Technique For Others Reference by Similarity to Ideal Solution) dirasa lebih cocok dengan kasus ini karena terdapatnya pemecahan unsur kriteria dan pembobotan pada masing-masing kriteria. Berdasarkan hasil studi kasus sistem seleksi menunjukan bahwa hasil perhitungan menggunakan sistem sama dengan perhitungan manual. Sistem ini mampu memberikan rekomendasi pemilihan dosen pembimbing.
\end{abstract}

Kata kunci: Pemilihan Dosen Pembimbing, TOPSIS, Sistem Pendukung Keputusan, Sistem Informasi.

\section{PENDAHULUAN}

Dalam sitem perkuliahan salah satu syarat untuk lulus dari program Sarjana adalah setiap mahasiswa harus membuat skripsi. Mahasiswa dibantu tim pembimbing dalam proses penyelesaian skripsinya. Tim pembimbing tersebut memberikan arahan dan masukan terhadap skripsi yang dikerjakan.

Pengajuan dosen pembimbing skripsi di Program Studi Pendidikan Teknik Informatika Universitas Negeri Malang ditangani oleh tim dosen Kelompok Bidang Keahlian (selanjutnya disebut KBK) dan Koordinator Program Studi (selanjutnya disebut Korprodi). Mahasiswa mengajukan sebuah judul skripsi kepada Tim KBK, apabila Tim KBK menyetujui judul tersebut maka Tim KBK meneruskan wewenang pemilihan dosen kepada Korprodi. Selanjutnya Korprodi menunjuk dua orang dosen pembimbing yang sesuai dengan judul skripsi yang telah diterima.

Penentuan dosen pembimbing skripsi yang sekarang dilakukan oleh Tim KBK dan Korprodi mempunyai keterbatasan yaitu dengan sekian banyak jumlah mahasiswa beserta judul yang diajukannya, Tim KBK dan Korprodi akan kesulitan memilah dosen yang sesuai dengan judul masing-masing mahasiswa. Selain itu Korprodi membutuhkan waktu yang lama untuk menyelesaikan banyaknya antrian dalam pengajuan dosen pembimbing. Korprodipun tidak sembarangan memutuskan dosen pembimbing yang sesuai, ada banyak faktor yang harus diperhitungkan matang-matang.

Dengan permasalahan-permasalahan di atas perlu dibangun sebuah sistem informasi yang dapat mempermudah Korprodi untuk menentukan dosen pembimbing skripsi yang sesuai dengan kriteria. Pemilihan metode TOPSIS (Technique For Others Reference by Similarity to Ideal Solution) dirasa lebih cocok dengan kasus ini karena terdapatnya pemecahan unsur kriteria dan pembobotan pada masing-masing kriteria.

\section{METODE PENELITIAN}

Salah satu model pengembangan perangkat lunak adalah model Waterfall. Model Waterfall merupakan model pengembangan perangkat lunak dengan pengerjaan yang sistematik dan berurutan.[1] Seorang pengembang harus mempunyai rencana dan membuat jadwal pengembangan sebagai acuan pengembangan sebelum mengerjakan proyeknya.

Model Waterfalmemiliki kelebihan yaitu tahapan proses pengembangan yang jelas, dokumentasi dihasilkan di setiap tahap pengembangan, dan setiap fase harus diselesaikan terlebih dahulu sebelum 
melanjutkan ke fase berikutnya, sehingga membuat kualitas perangkat lunak lebih baik dan minim kesalahan.[2] Namun model ini hanya sesuai dipakai untuk mengembangkan perangkat lunak apabila definisi kebutuhan sistem sudah ada dengan jelas dan meminimalisir perubahan kebutuhan sistem saat proses pengembangan berjalan.[3] Tahapan pada model Waterfall merupakan bentuk dasar pada model pengembangan lain. Tahapan pada model Waterfall terdapat pada gambar 1.

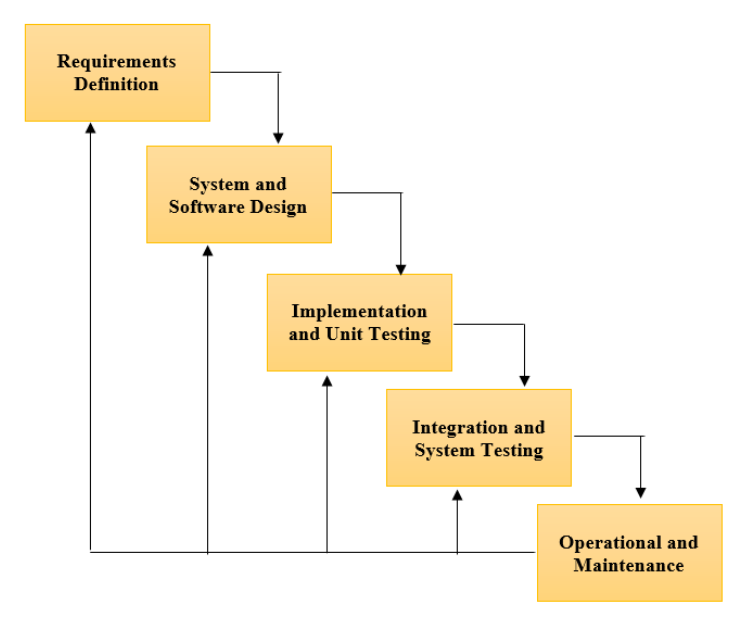

Gambar 1. Tahap pengembangan dengan model Waterfall

\section{Analisis dan definisi permasalahan}

Proses menganalisis kebutuhan sistem yang nantinya menjadi spesifikasi sistem secara detail seperti kelengkapan fitur, autentifikasi sistem, tujuan sistem dan batasan sistem. Data hasil observasi dari para pengguna sistem dikumpulkan yang selanjutnya digunakan untuk pengembangan sistem.

\section{Perancangan sistem dan perangkat lunak}

Pada proses desain dilakukan penerjemaan kebutuhan sistem dari pengguna agar lebih mudah untuk dilakukan pengkodean (coding). Proses desain ini berfokus pada kriteria berikut struktur data, arsitektur perangkat lunak, representasi interface, dan detail algoritma prosedural.

Algoritma TOPSIS adalah salah satu algoritma pendukung keputusan dengan banyak kriteria dan pada setiap kriteria memiliki nilai bobot sendiri[4]. Algoritma TOPSIS ini mempertimbangkan keduanya antara jarak solusi ideal positif dan solusi ideal negatif. Jadi alternatif yang dihasilkan adalah alternatif yang terletak dekat dengan solusi ideal positif dan jauh dari solusi ideal negatif. Berikut ini langkah-langkah algoritma dari metode TOPSI.[4]

a. Menggambarkan alternatif $(m)$ dan kriteria (n) ke dalam sebuah matriks keputusan (D), Dengan Xij menyatakan performansi dari perhitungan untuk alternatif ke-i terhadap kriteria ke-j. Matriks ini dapat dilihat pada persamaan (1) berikut

$$
D=\left[\begin{array}{lll}
X_{11} & X_{12 . .} & X_{1 n} \\
X_{21} & X_{22 . .} & X_{2 n} \\
X_{m 1} & X_{m 2 . .} & X_{m n}
\end{array}\right]
$$

dimana $\mathrm{m}=$ jumlah alternatif yang ada; $\mathrm{n}=$ jumlah kriteria yang ada

b. Membuat matriks $R$ yaitu matriks keputusan ternormalisasi dengan perhitungan menggunakan persamaan (2) :

$$
\begin{gathered}
R=\left[\begin{array}{lll}
r_{11} & r_{12 . .} & r_{1 j} \\
r_{21} & r_{22 . .} & r_{2 j} \\
r_{i 1} & r_{i 2 . .} & r_{i j}
\end{array}\right] \\
r_{i j}=\frac{x_{i j}}{\sqrt{\sum_{i=1}^{m} x_{i j}^{2}}}
\end{gathered}
$$

jika rumus di atas diturunkan

$$
r_{11}=\frac{x_{11}}{\sqrt{x_{11}{ }^{2}+x_{21}{ }^{2}+\cdots+x_{m 1}^{2}}}
$$

Dimana :

$\mathrm{r}_{\mathrm{ij}}$ adalah elemen dari matriks keputusan ternormalisasi ( $R$ )

$x_{i j}$ adalah elemen dari matriks keputusan (D)dengan $\mathrm{i}=1,2,3 \ldots . \mathrm{m}$; dan $\mathrm{j}=$ $1,2,3 . . . . n$.

c. Membangun matrik keputusan ternormalisasi dengan bobot $(\mathrm{Y})$, yang elemen-elemen matriksnya dapat dihitung dengan persamaan(3) berikut:

$$
\begin{gathered}
Y_{i j}=W_{j} r_{i j} \\
Y=\left[\begin{array}{ccc}
W_{1} r_{11} & W_{2} r_{12} & W_{j} r_{1 j} \\
W_{1} r_{21} & \ldots & \ldots \\
W_{1} r_{i 1} & W_{2} r_{i 2} & W_{j} r_{i j}
\end{array}\right]
\end{gathered}
$$

$Y_{i j}$ adalah elemen dari matriks keputusan ternormalisasi terbobot $(\mathrm{Y})$

dengan $i=1,2,3 \ldots . . m$; dan $j=1,2,3 \ldots . . n$.

d. Menghitung matriks solusi ideal positif $\left(A^{+}\right)$ dan matriks solusi ideal negatif $\left(A^{-}\right)$ berdasarkan rating bobot ternormalisasi di poin tiga. Perlu diperhatikan bahwa agar 
dapat menghitung solusi ideal negatif atau positif, harus di bedakan antara mana yang bersifat keuntungan dan mana yang bersifat biaya dengan persamaan (4) berikut :

$$
\begin{aligned}
& A^{+}=\left(y_{1}^{+}, y_{2}^{+}, \ldots \ldots, y_{n}^{+}\right) \\
& A^{-}=\left(y_{1}^{-}, y_{2}^{-}, \ldots . ., y_{n}^{-}\right)
\end{aligned}
$$

Dimana,

$A_{j}^{+}$adalah :

- $\max Y_{\mathrm{ij}}$, jika j adalah kriteria keuntungan

- $\min Y_{i j}$, jika j adalah kriteria biaya

$A_{j}^{-}$adalah :

- $\min Y_{\mathrm{ij}}$, jika $\mathrm{j}$ adalah kriteria keuntungan

- $\max Y_{i j}$, jika j adalah kriteria biaya

e. Menghitung jarak antara nilai setiap alternatif dengan matriks solusi ideal positif (separasi positif) dan matriks solusi ideal negatif (seperasi negatif).

Jarak antara alternatif $A_{i}$ dengan solusi ideal positif dirumuskan dengan persamaan (5) sebagai berikut:

$S_{i}^{+}=\sqrt{\sum_{j=1}^{n}\left(Y_{j}^{+}-Y_{i j}\right)^{2}}$
dimana $\mathrm{i}=1,2,3, \ldots \mathrm{m}$

Jarak antara alternatif $A_{i}$ dengan solusi ideal negatif dirumuskan dengan persamaan (6) sebagai berikut :

$S_{i}^{-}=\sqrt{\sum_{j=1}^{n}\left(Y_{i j}-Y_{j}^{-}\right)^{2}}$

dimana $i=1,2,3, \ldots m$

f. Menghitung nilai preferensi untuk setiap alternatif

Nilai preferensi untuk setiap alternatif $\left(\mathrm{V}_{\mathrm{i}}\right)$ dapat dihitung dengan persamaan (7) ini :

$$
\begin{aligned}
& V_{i}=\frac{D_{i}^{-}}{D_{i}^{-}+D_{i}^{+}} \\
& \text {dimana } \mathrm{i}=1,2,3, \ldots \mathrm{m}
\end{aligned}
$$

Nilai $V_{i}$ yang lebih besar menunjukkan bahwa alternatifAi lebih dipilih.

\section{Implementasi dan pengujian unit}

Pada tahap ini dilakukan pengkodean sistem atau menerjemahkan kebutuhan manusia (pengguna) kedalam bahasa yang mudah dipahami sistem. Setelah pengkodean, dilanjutkan dengan pengujian masing-masing unit apakah sudah sesuai dengan deskriptif pengguna.
4. Integrasi dan pengujian sistem.

Pada proses ini dilakukan pengujian secara keseluruhan apakah unit-unit dari sistem tersebut sudah terintegrasi dan sudah memenuhi kebutuhan sistem yang diharapkan pengguna.

\section{Pengoperasian dan perawatan.}

Merupakan bagian paling akhir dari siklus pengembangan pada siklus ini dilakukan pengembangan lagi apabila ditemukannya beberapa kesalahan sistem setelah pemakaian oleh pengguna, apabila tidak terdapat kesalahan oleh sistem maka sistem akan ditambah fitur-fiturnya, ditingkatkan kinerja sistemnya dan sebagainya.

\section{HASIL DAN PEMBAHASAN}

Sistem pendukung keputusan pemilihan dosen pembimbing skripsi ini menggunakan model pengembangan Waterfall, berikut tahapan model pengembangan Waterfall.

\section{Analisis dan definisi permasalahan}

Proses awal pada pengembangan ini adalah melakukan analisis kebutuhan sistem pendukung keputusan pemilihan dosen pembimbing. Proses yang dilakukan adalah wawancara dengan Korprodi Pendidikan Teknik Informatika untuk menemukan kriteriakriteria apa saja yang dibutuhkan saat menentukan dosen pembimbing.

Setelah penulis melakukan wawancara dengan Korprodi Pendidikan Teknik Informatika didapatkan kriteria-kriteria yang dibutuhkan untuk sistem pendukung keputusan pemilihan dosen pembimbing skripsi ini diantaranya adalah : (1) kompetensi dan bidang keahlian dosen, (2) tingkat Pendidikan dosen, (3) pangkat dan fungsionalitas dosen, (4) jumlah total mahasiswa yang dibimbing oleh seorang dosen, (5) jadwal bimbingan dosen, (6) durasi dalam setiap kali bimbingan dan (7) layanan konsultasi

\section{Perancangan sistem dan perangkat lunak}

Pada proses desain ini berfokus pada perancangan arsitektur perangkat lunak (data flow diagram, perancangan database, representasi interface, dan Perancangan Sistem Pendukung Keputusan). 


\section{a. Data Flow Diagram}

DFD (Data Flow Diagram) adalah alur perjalanan sistem dan data yang digambarkan dalam bentuk symbol.[5]

DFD dari sistem pendukung keputusan pemilihan dosen pembimbing skripsi dapat dilihat pada gambar 2. DFD tersebut menggambarkan bahwa sistem dirancang dengan tiga pengguna.

Pertama admin (laboran) memberikan masukan kepada sistem berupa data mahasiswa, data dosen dan identitas admin.
Setelah diolah admin akan mendapatkan hasil rekomendasi dosen pembimbing.

Kedua dosen tim KBK, pada pengguna ini hanya dapat memberikan masukan kepada sistem berupa identitas pengguna dan konfirmasi hasil judul mahasiswa.

Ketiga dosen Korprodi dapat memberikan masuka berupa identitas pengguna dan dosen pembimbing yang dipilih. Untuk keluaran dari sistem berupa hasil rekomendasi dosen pembimbing dan hasil pemilihan dosen pembimbing

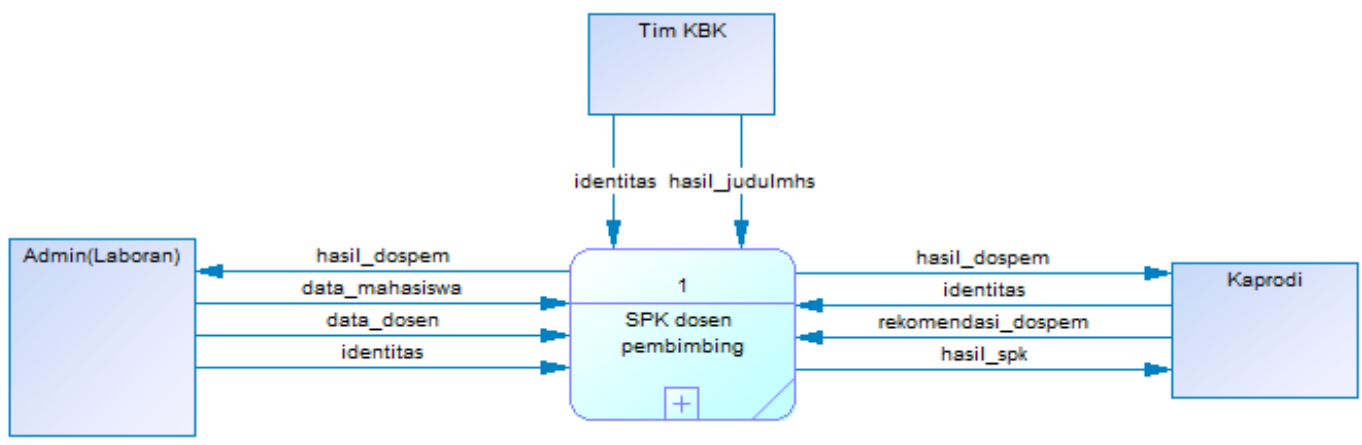

Gambar 2. DFD sistem pendukung keputusan pemilihan dosen pembimbing skripsi

\section{b. Perancangan database}

Pemodelan databasedalam perancangan sistem menggunakanentity relationship diagram (ERD). ERD adalah penggambaran hubungan antara data dan pengguna/entitas dengan menggunakan symbol dan garis.[6]

Sistem ini memiliki beberapa tabel inti diantaranya, tabel mahasiswa yang menyimpan identitas mahasiswa. Tabel dosen menyimpan identitas dosen. Tabel skripsi menyimpan skripsi mahasiswa beserta hasil dosen pembimbing yang didapatkan. Tabel konfirmasi_skripsi menyimpan hasil penolakan atau penerimaan judul skripsi. Tabel prodi menyimpan informasi prodi. Tabel kbk menyimpan kelompok bidang studi yang ada dalam sistem. Tabel topsis_ctriterias menyimpan kriteria-kriteria yang digunakan untuk perhitungan. Tabel topsis subkriterias menyimpan subkriteria yang digunakan untuk perhitungan sistem. Dan tabel topsis_evaluations digunakan untuk menyimpan hasil perhitungan sistem. Berikut pemodelan data dengan menggunakan ERD terdapat pada gambar 3 .

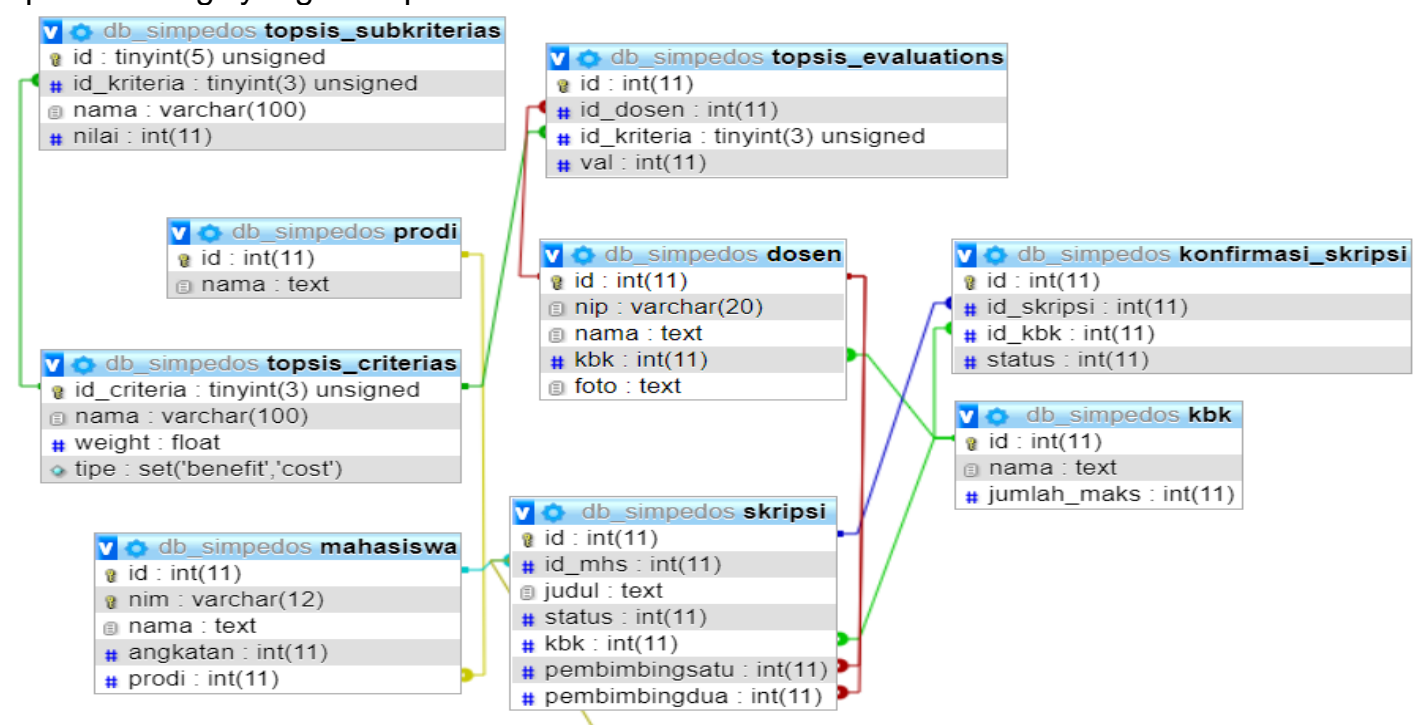

Gambar 3. ERD sistem pendukung keputusan pemilihan dosen pembimbing skripsi 
c. Representasi interface

Pada halaman utama menampilkan statistik data sistem seperti jumlah user, jumlah skripsi masuk, jumlah skripsi diterima, jumlah skripsi yang ditolak dan informasi sistem seperti terlihat pada gambar 4 .

Dosen tim KBK bertugas melakukan konfirmasi terhadap pengajuan judul skripsi mahasiswa. Pada halaman konfirmasi skripsi menampilkan antrian pengajuan judul skripsi dari mahasiswa. Tim KBK dapat melakukan konfirmasi dengan cara menekan tombol setujui atau tombol tolak seperti pada gambar 5

Dosen Korprodi bertugas menunjuk dosen pembimbing skripsi I dan dosen pembimbing skripsi II. Pada halaman konfirmasi skripsi ditampilkan antrian judul skripsi yang telah disetujui tim KBK. Korprodi menekan tombol proses pada halaman konfirmasi skripsi untuk menampilkan rekomendasi dosen berdasarkan perhitungan sistem seperti pada gambar 6. Setelah itu, Korprodi dapat memilih dosen pembimbing seperti pada gambar 7 .

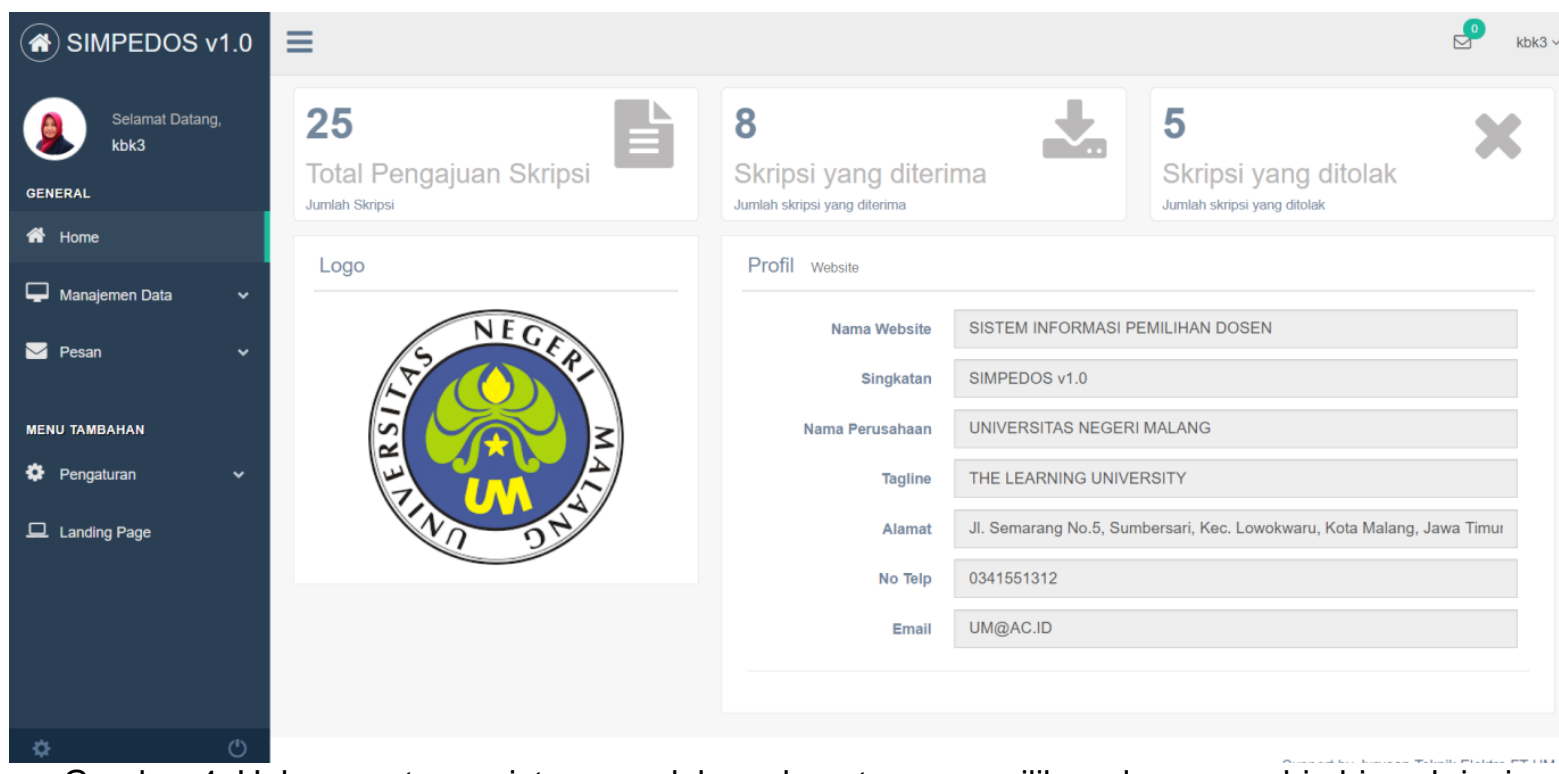

Gambar 4. Halaman utama sistem pendukung keputusan pemilihan dosen pembimbing skripsi

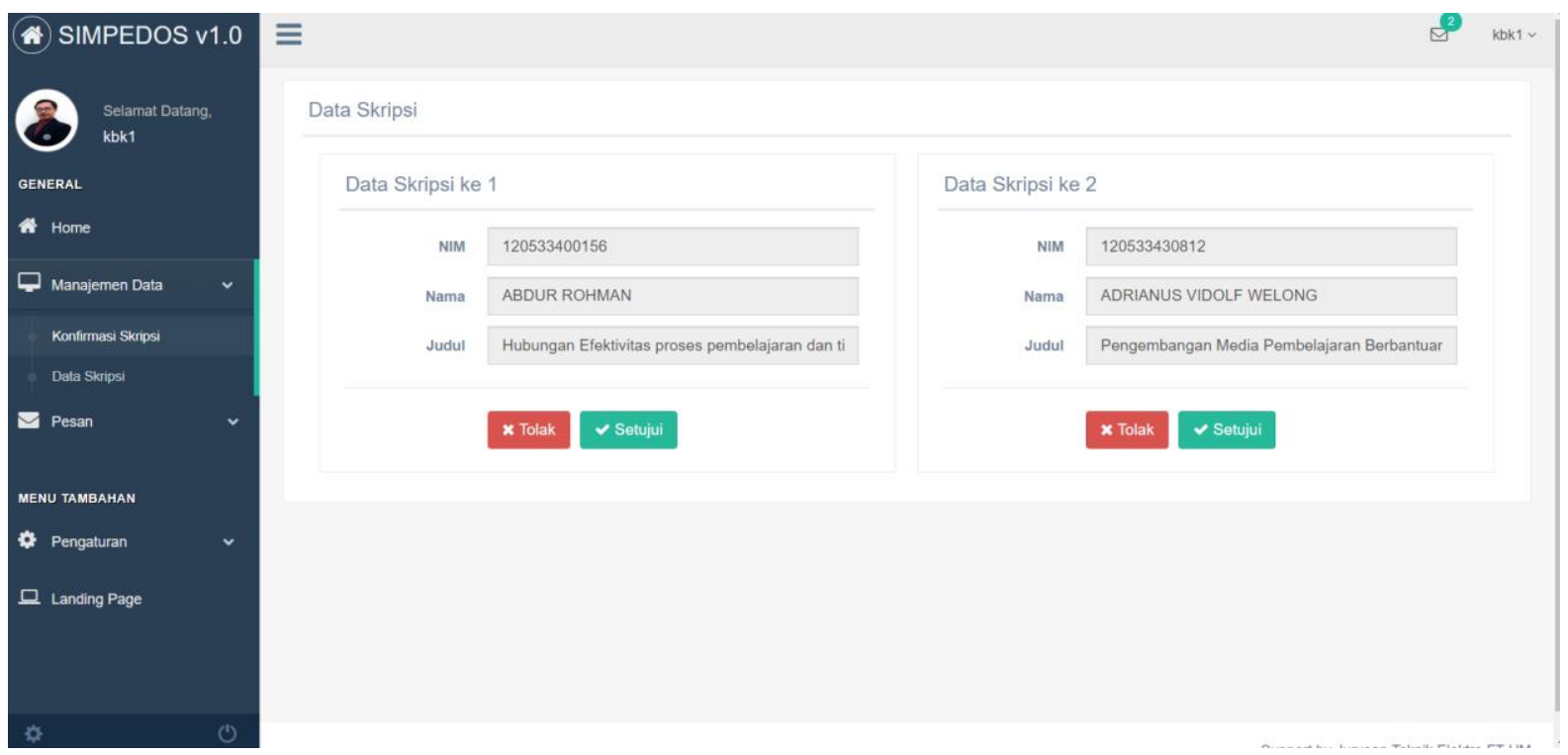

Gambar 5. Halaman konfirmasi skripsi oleh tim dosen KBK 

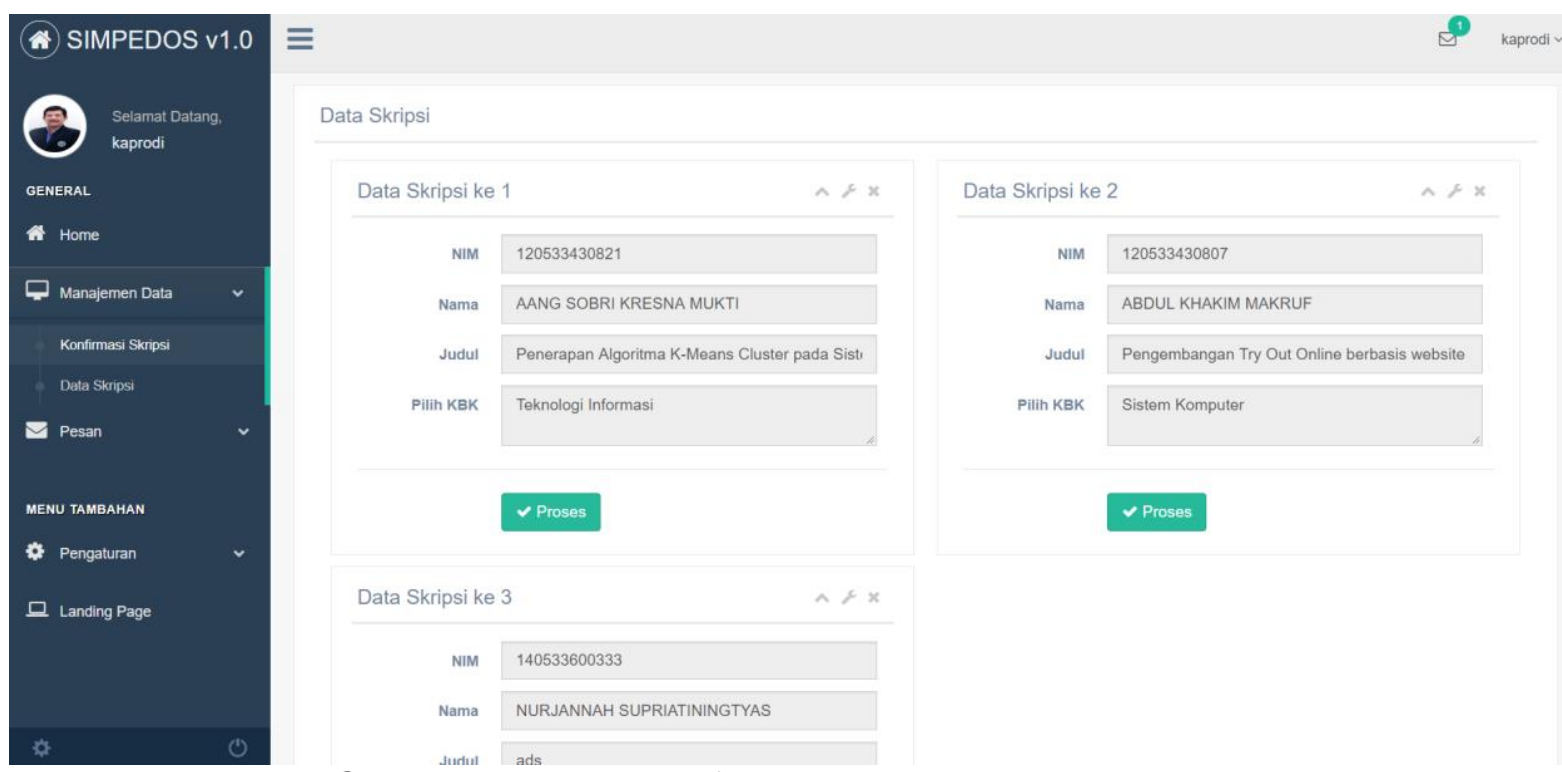

Gambar 6. Halaman konfirmasi skripsi oleh dosen Korprodi

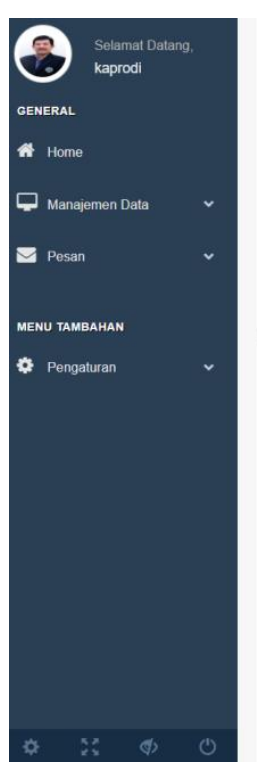

Data Skripsi

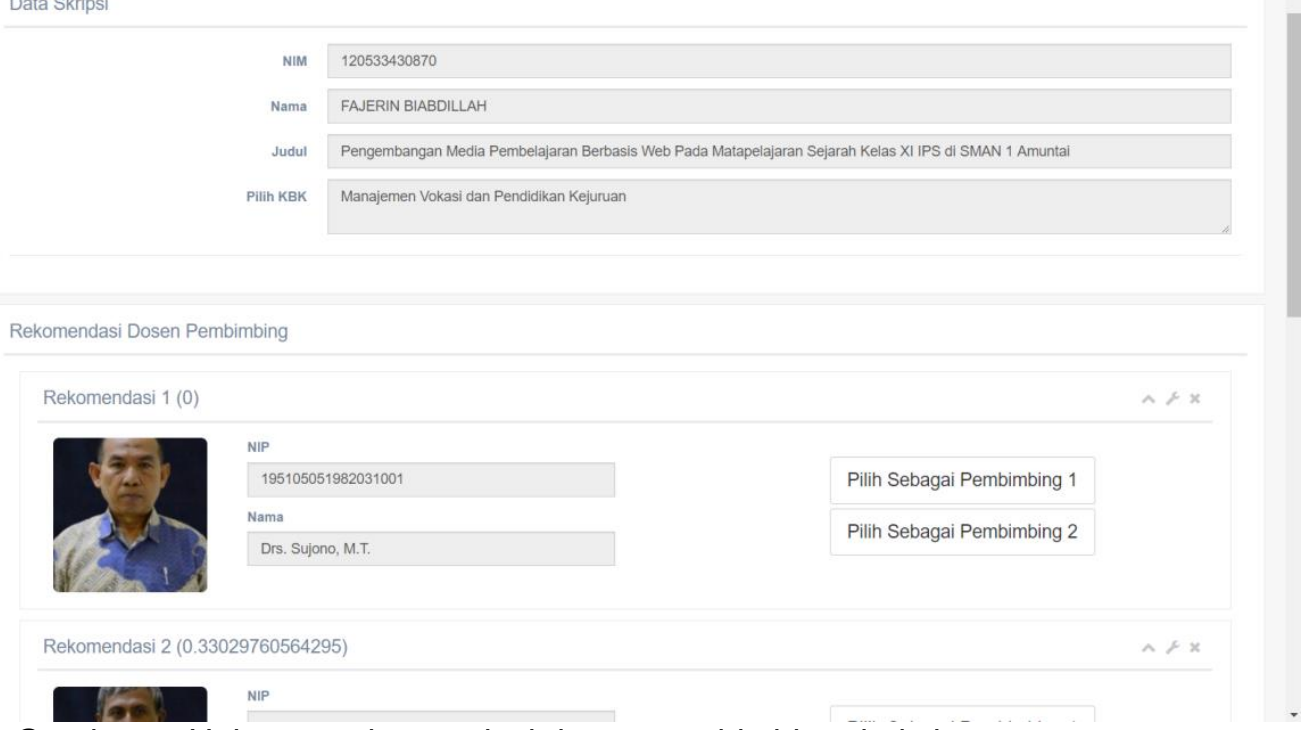

Gambar 7. Halaman rekomendasi dosen pembimbing dari sistem

d. Perancangan sistem pendukung keputusan

Algoritma sistem menggunakan metode TOPSIS. Berikut perhitungan studi kasus menggunakan cara manual.

1) Menentukan jenis-jenis kriteria.

Ada tujuh kriteria (1) kompetensi dan bidang keahlian dosen, (2) tingkat Pendidikan dosen, (3) pangkat dan fungsionalitas dosen,
(4) jumlah total mahasiswa yang dibimbing oleh seorang dosen, (5) jadwal bimbingan dosen, (6) durasi dalam setiap kali bimbingan dan (7) layanan konsultasi.

2) Membuat rangking pada setiap Kriteria

Misal kriteria A mempunya rangking sebagai berikut: 
Tabel 1. Tabel perangkingan kriteria

\begin{tabular}{|c|c|c|c|}
\hline Kriteria & Kode & Sub Kriteria & Ranking \\
\hline \multirow{6}{*}{$\begin{array}{l}\text { Kompetensi dan } \\
\text { Keahlian }\end{array}$} & \multirow{6}{*}{ C1 } & Manajemen Vokasi dan Pendidikan Kejuruan & 1 \\
\hline & & $\begin{array}{l}\text { Kurikulum dan Pembelajaran pada Vokasi dan } \\
\text { Pendidikan Kejuruan }\end{array}$ & 2 \\
\hline & & $\begin{array}{l}\text { Evaluasi Pembelajaran Vokasi dan Pendidikan } \\
\text { Kejuruan }\end{array}$ & 3 \\
\hline & & Sistem Komputer & 4 \\
\hline & & Rekayasa Perangkat Lunak & 5 \\
\hline & & Teknologi Informasi & 6 \\
\hline \multirow{2}{*}{$\begin{array}{l}\text { Tingkat Pendidikan } \\
\text { Dosen }\end{array}$} & \multirow{2}{*}{ C2 } & S2 & 1 \\
\hline & & S3 & 2 \\
\hline \multirow{5}{*}{ Fungsionalitas } & \multirow{5}{*}{ C3 } & Tenaga Pengajar & 1 \\
\hline & & Asisten Ahli & 2 \\
\hline & & Lektor & 3 \\
\hline & & Lektor Kepala & 4 \\
\hline & & Guru Besar & 5 \\
\hline \multirow{5}{*}{ Jumlah Bimbingan } & \multirow{5}{*}{ C4 } & $21-25$ & 1 \\
\hline & & $16-20$ & 2 \\
\hline & & $11-15$ & 3 \\
\hline & & $6-10$ & 4 \\
\hline & & $0-5$ & 5 \\
\hline \multirow{5}{*}{$\begin{array}{l}\text { Jadwal Bimbingan yang } \\
\text { Kosong Selama Satu } \\
\text { Minggu }\end{array}$} & \multirow{5}{*}{ C5 } & $0-3$ & 1 \\
\hline & & $4-6$ & 2 \\
\hline & & $7-9$ & 3 \\
\hline & & $10-12$ & 4 \\
\hline & & 13-15 & 5 \\
\hline \multirow{3}{*}{$\begin{array}{l}\text { Durasi dalam setiap } \\
\text { bimbingan }\end{array}$} & \multirow{3}{*}{ C6 } & $<=10$ menit & 1 \\
\hline & & $>10$ menit $<=20$ menit & 2 \\
\hline & & $>20$ menit $<=30$ menit & 3 \\
\hline \multirow{3}{*}{ Layanan Konsultasi } & \multirow{3}{*}{ C7 } & Via Dunia Maya & 1 \\
\hline & & Bertemu Langsung & 2 \\
\hline & & Bertemu Langsung dan Via dunia maya & 3 \\
\hline
\end{tabular}

3) Mengumpulkan data awal (belum terangking) pada setiap alternatif dan setiap kriteria terlihat pada tabel 2.

Keterangan :

Alternatif $A 1$ : Dosen $A$

Alternatif $A 2$ : Dosen $B$

Alternatif $A 3$ : Dosen $C$

Alternatif A5 : Dosen E

Alternatif A4 : Dosen D

4) Membuat matriks kecocokan rangking setiap alternatif pada tiap-tiap kriteria dari kumpulan data awal. Hasil dari matriks kecocokan setiap alternatif pada tiap-tiap kriteria nantinya akan disebut matriks keputusan terlihat pada tabel 3 .

Tabel 2. Tabel data awal sistem pendukung keputusan

\begin{tabular}{clcccccc}
\hline \multirow{2}{*}{ Alternatif } & \multicolumn{1}{c}{ C1 } & C2 & C3 & C4 & C5 & C6 & \multicolumn{1}{c}{ C7 } \\
\cline { 2 - 7 } A1 & $\begin{array}{l}\text { Manajemen Vokasi dan Pendidikan } \\
\text { Kejuruan }\end{array}$ & S2 & $\begin{array}{l}\text { Tenaga } \\
\text { Pengajar }\end{array}$ & 21 & 5 & 8 & $\begin{array}{l}\text { Bertemu } \\
\text { Langsung }\end{array}$ \\
\hline A2 & $\begin{array}{l}\text { Evaluasi Pembelajaran Vokasi dan } \\
\text { Pendidikan Kejuruan }\end{array}$ & S2 & $\begin{array}{l}\text { Tenaga } \\
\text { Pengajar }\end{array}$ & 16 & 6 & 15 & $\begin{array}{l}\text { Bertemu } \\
\text { Langsung }\end{array}$ \\
\hline A3 & Sistem Komputer & S3 & $\begin{array}{l}\text { Lektor } \\
\text { Kepala }\end{array}$ & 15 & 8 & 10 & $\begin{array}{l}\text { Bertemu } \\
\text { Langsung }\end{array}$ \\
\hline A4 & Rekayasa Perangkat Lunak & S2 & $\begin{array}{l}\text { Asisten } \\
\text { Ahli }\end{array}$ & 5 & 5 & 22 & $\begin{array}{l}\text { Langsung dan } \\
\text { Via dunia } \\
\text { maya }\end{array}$ \\
\hline A5 & $\begin{array}{l}\text { Evaluasi Pembelajaran Vokasi dan } \\
\text { Pendidikan Kejuruan }\end{array}$ & S3 & $\begin{array}{l}\text { Lektor } \\
\text { Kepala }\end{array}$ & 23 & 8 & 8 & $\begin{array}{l}\text { Bertemu } \\
\text { Langsung }\end{array}$ \\
\hline
\end{tabular}


Tabel 3. Kecocokan rangking setiap alternatif pada tiap-tiap kriteria

\begin{tabular}{cccccccc}
\hline \multirow{2}{*}{ Alternatif } & \multicolumn{7}{c}{ Kriteria } \\
\cline { 2 - 8 } & C1 & C2 & C3 & C4 & C5 & C6 & C7 \\
\hline A1 & 1 & 1 & 1 & 1 & 2 & 1 & 2 \\
\hline A2 & 3 & 1 & 1 & 2 & 2 & 2 & 2 \\
\hline A3 & 4 & 2 & 4 & 3 & 3 & 1 & 2 \\
\hline A4 & 5 & 1 & 2 & 5 & 2 & 3 & 3 \\
\hline A5 & 3 & 2 & 4 & 1 & 3 & 1 & 2 \\
\hline
\end{tabular}

5) Menentukan bobot preferensi untuk setiap kriteria
a) Bobot kriteria Kompensi dan Keahlian $(\mathrm{C} 1)=5$
b) Bobot kriteria Tingkat Pendidikan Dosen $(\mathrm{C} 2)=4$
c) Bobot kriteria Fungsionalitas (C3) $=3$
d) Bobot kriteria Jumlah Bimbingan (C4) $=5$
e) Bobot kriteria Bimbingan yang kosong $(\mathrm{C} 5)=2$
f) Bobot kriteria Durasi dalam setiap bimbingan $(\mathrm{C} 6)=3$
g) Bobot kriteria Layanan Konsultasi (C7) $=2$

Setelah data-data diatas terbentuk langkah selanjutnya adalah menghitung rekomendasi yang dihasilkan dengan metode TOPSIS sebagai berikut :

1) Dengan menggunakan persamaan (1) dan hasil pengumpulan data di atas dapat terbentuk sebuah matriks keputusan (D) sebagai berikut :

$$
\mathrm{D}=\begin{array}{|l|l|l|l|l|l|l|}
\hline 1 & 1 & 1 & 1 & 2 & 1 & 2 \\
\hline 3 & 1 & 1 & 2 & 2 & 2 & 2 \\
\hline 4 & 2 & 4 & 3 & 3 & 1 & 2 \\
\hline 5 & 1 & 2 & 5 & 2 & 3 & 3 \\
\hline 3 & 2 & 4 & 1 & 3 & 1 & 2 \\
\hline
\end{array}
$$

2) Dari matriks keputusan (D) dapat dibentuk matriks keputusan ternormalisasi (R)dengan menggunakan persamaan (2) sebagai berikut:

$R=\quad$\begin{tabular}{|l|l|l|l|l|l|l|}
\hline 0,1291 & 0,3015 & 0,1622 & 0,1581 & 0,3651 & 0,2500 & 0,4000 \\
\hline 0,3873 & 0,3015 & 0,1622 & 0,3162 & 0,3651 & 0,5000 & 0,4000 \\
\hline 0,5164 & 0,6030 & 0,6489 & 0,4743 & 0,5477 & 0,2500 & 0,4000 \\
\hline 0,6455 & 0,3015 & 0,3244 & 0,7906 & 0,3651 & 0,7500 & 0,6000 \\
\hline 0,3873 & 0,6030 & 0,6489 & 0,1581 & 0,5477 & 0,2500 & 0,4000 \\
\hline
\end{tabular}

3) Dari matriks keputusan ternormalisasi (R) langkah selanjutnya adalah dibangun matrik keputusan ternormalisasi dengan bobot $(\mathrm{Y})$, yang elemen-elemen matriksnya dapat dihitung dengan persamaan (3) dengan penjabaran sebagai berikut :

$$
\begin{aligned}
& Y_{11}=W_{1} r_{11}=5 \times 0,1291=0,6455 \\
& Y_{21}=W_{1} r_{21}=5 \times 0,3873=1,9365 \\
& Y_{31}=W_{1} r_{31}=5 \times 0,5164=2,5820 \\
& Y_{41}=W_{1} r_{41}=5 \times 0,6455=3,2275 \\
& Y_{51}=W_{1} r_{51}=5 \times 0,3873=1,9365
\end{aligned}
$$

$$
\begin{aligned}
& Y_{12}=W_{2} r_{12}=4 \times 0,3015=1,2060 \\
& Y_{22}=W_{2} r_{22}=4 \times 0,3015=1,2060 \\
& Y_{32}=W_{2} r_{32}=4 \times 0,6030=2,4121 \\
& Y_{42}=W_{2} r_{42}=4 \times 0,3015=1,2060 \\
& Y_{52}=W_{2} r_{52}=4 \times 0,6030=2,4121
\end{aligned}
$$

Demikian seterusnya sehingga terbentuk matriks keputusan ternormalisasi dengan bobot $(Y)$ sebagai berikut : 


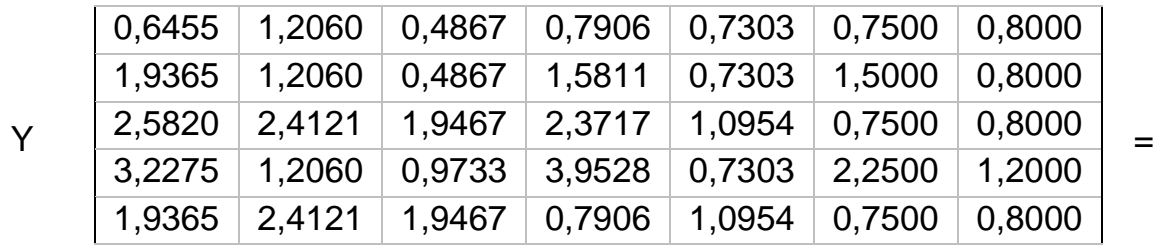

4) Selanjutnyamenghitung matriks solusi ideal positif $\left(\mathrm{A}^{+}\right)$dan matriks solusi ideal negatif $\left(A^{-}\right)$dengan menggunakan persamaan (4) dimana semua kriteria merupakan kriteria benefit (keuntungan) semakin besar nilainya maka semakin dekat dengan solusi ideal positif. Seperti gambaran berikut :

$A_{j}^{+}$adalah : - $\max \mathrm{Y}_{\mathrm{ij}}$, jika j adalah kriteria keuntungan

$A_{j}^{-}$adalah : - $\min \mathrm{Y}_{\mathrm{ij}}$, jika j adalah kriteria keuntungan

Berikut mencari elemen matriks solusi ideal positif $\left(A^{+}\right)$

$$
\begin{aligned}
& A_{1}^{+}=\operatorname{MAX}\left(Y_{11}, Y_{21}, Y_{31}, Y_{41}, Y_{51}\right)=3,2275 \\
& A_{2}^{+}=\operatorname{MAX}\left(Y_{12}, Y_{22}, Y_{32}, Y_{42}, Y_{52}\right)=2,4121 \\
& A_{3}^{+}=\operatorname{MAX}\left(Y_{13}, Y_{23}, Y_{33}, Y_{43}, Y_{53}\right)=1,9467 \\
& A_{4}^{+}=\operatorname{MAX}\left(Y_{14}, Y_{24}, Y_{34}, Y_{44}, Y_{54}\right)=3,9528 \\
& A_{5}^{+}=\operatorname{MAX}\left(Y_{15}, Y_{25}, Y_{35}, Y_{45}, Y_{55}\right)=1,0954 \\
& A_{6}^{+}=\operatorname{MAX}\left(Y_{16}, Y_{26}, Y_{36}, Y_{46}, Y_{56}\right)=2,2500 \\
& A_{7}^{+}=\operatorname{MAX}\left(Y_{17}, Y_{27}, Y_{37}, Y_{47}, Y_{57}\right)=1,2000
\end{aligned}
$$

Dan terbentuklah matriks solusi ideal positif $\left(\mathrm{A}^{+}\right)$sebagai berikut :

$\mathrm{A}^{+}=$

\begin{tabular}{|r|r|r|r|r|r|r|}
\hline 3,22 & 2,41 & 1,94 & 3,95 & 1,09 & 2,25 & 1,20 \\
75 & 21 & 67 & 28 & 54 & 00 & 00 \\
\hline
\end{tabular}

Berikut mencari elemen matriks solusi ideal negatif $\left(A^{-}\right)$

$$
\begin{aligned}
& A_{1}^{-}=\operatorname{MIN}\left(Y_{11}, Y_{21}, Y_{31}, Y_{41}, Y_{51}\right)=0,6455 \\
& A_{2}^{-}=\operatorname{MIN}\left(Y_{12}, Y_{22}, Y_{32}, Y_{42}, Y_{52}\right)=1,2060 \\
& A_{3}^{-}=\operatorname{MIN}\left(Y_{13}, Y_{23}, Y_{33}, Y_{43}, Y_{53}\right)=0,4867 \\
& A_{4}^{-}=\operatorname{MIN}\left(Y_{14}, Y_{24}, Y_{34}, Y_{44}, Y_{54}\right)=0,7906 \\
& A_{5}^{-}=\operatorname{MIN}\left(Y_{15}, Y_{25}, Y_{35}, Y_{45}, Y_{55}\right)=0,7303 \\
& A_{6}^{-}=\operatorname{MIN}\left(Y_{16}, Y_{26}, Y_{36}, Y_{46}, Y_{56}\right)=0,7500 \\
& A_{7}^{-}=\operatorname{MIN}\left(Y_{17}, Y_{27}, Y_{37}, Y_{47}, Y_{57}\right)=0,8000
\end{aligned}
$$

Dan terbentuklah matriks solusi ideal negatif $\left(\mathrm{A}^{-}\right)$sebagai berikut :
$\mathrm{A}^{-}=$

\begin{tabular}{|r|r|r|r|r|r|r|}
\hline 0,64 & 1,20 & 0,48 & 0,79 & 0,73 & 0,75 & 0,80 \\
55 & 60 & 67 & 06 & 03 & 00 & 00 \\
\hline
\end{tabular}

5) Setelah terbuat matriks solusi ideal positis dan solusi ideal negatif sekarang menghitung jarak antara nilai setiap alternatif dengan matriks solusi ideal positif (separasi positif) dan matriks solusi ideal negatif (seperasi negatif).

Berikut menghitung jarak $\left(\mathrm{S}^{+}\right)$antara alternatif $A_{i}$ dengan solusi ideal positif menggunakan persamaan (5) :

$$
\begin{aligned}
& S_{1}^{+}= \\
& \sqrt{\begin{array}{c}
\left(Y_{1}^{+}-Y_{11}\right)^{2}+\left(Y_{2}^{+}-Y_{12}\right)^{2}+\left(Y_{3}^{+}-Y_{13}\right)^{2}+\cdots \\
+\left(Y_{7}^{+}-Y_{17}\right)^{2}
\end{array}} \\
& =4,7745 \\
& S_{2}^{+}= \\
& \sqrt{\begin{array}{c}
\left(Y_{1}^{+}-Y_{21}\right)^{2}+\left(Y_{2}^{+}-Y_{22}\right)^{2}+\left(Y_{3}^{+}-Y_{23}\right)^{2}+\cdots \\
+\left(Y_{7}^{+}-Y_{27}\right)^{2}
\end{array}} \\
& =3,4254 \\
& S_{3}^{+}= \\
& \sqrt{\begin{array}{c}
\left(Y_{1}^{+}-Y_{31}\right)^{2}+\left(Y_{2}^{+}-Y_{32}\right)^{2}+\left(Y_{3}^{+}-Y_{33}\right)^{2}+\cdots \\
+\left(Y_{7}^{+}-Y_{37}\right)^{2}
\end{array}} \\
& =2,3080 \\
& S_{4}^{+}= \\
& \sqrt{\begin{array}{c}
\left(Y_{1}^{+}-Y_{41}\right)^{2}+\left(Y_{2}^{+}-Y_{42}\right)^{2}+\left(Y_{3}^{+}-Y_{43}\right)^{2}+\cdots \\
+\left(Y_{7}^{+}-Y_{47}\right)^{2}
\end{array}} \\
& =1,5922 \\
& S_{5}^{+}= \\
& \begin{array}{c}
\sqrt{\begin{array}{c}
\left.Y_{1}^{+}-Y_{51}\right)^{2}+\left(Y_{2}^{+}-Y_{52}\right)^{2}+\left(Y_{3}^{+}-Y_{53}\right)^{2}+\cdots \\
+\left(Y_{7}^{+}-Y_{57}\right)^{2}
\end{array}} \\
=3,7519 \quad{ }^{2}
\end{array}
\end{aligned}
$$

Berikut menghitung jarak (S-) antara alternatif $A_{i}$ dengan solusi ideal negatif menggunakan persamaan (6) :

$$
\begin{aligned}
& S_{1}^{-}= \\
& \sqrt{\begin{array}{c}
\left(Y_{11}-Y_{1}^{-}\right)^{2}+\left(Y_{12}-Y_{2}^{-}\right)^{2}+\left(Y_{13}-Y_{3}^{-}\right)^{2}+\cdots \\
+\left(Y_{17}-Y_{7}^{-}\right)^{2}
\end{array}} \\
& =0
\end{aligned}
$$




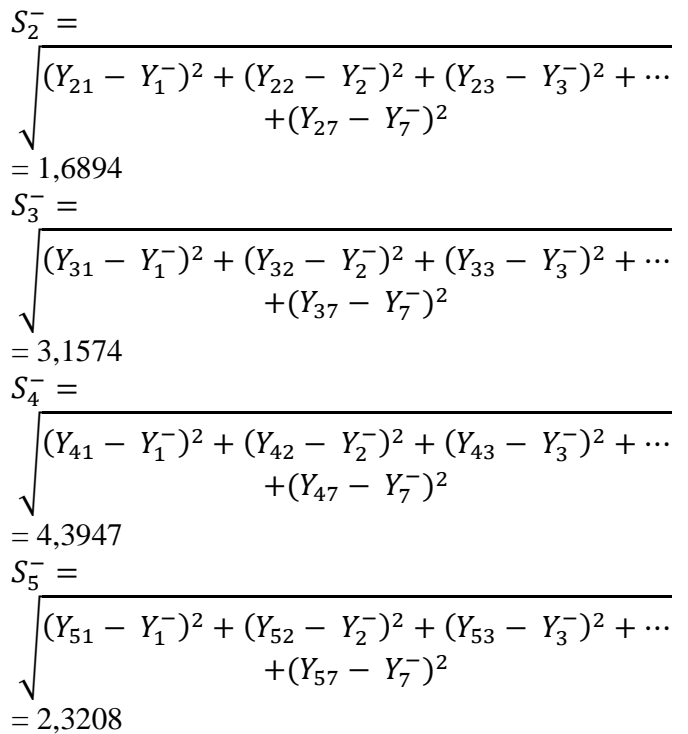

6) Menghitung nilai preferensi untuk setiap alternatif $\left(V_{i}\right)$ dengan menggunakan persamaan (7) :

$$
V_{1}=\frac{D_{1}^{-}}{D_{1}^{-}+D_{1}^{+}}=\frac{0}{0+4,7745}=0 \rightarrow
$$

Alternatif 1 (Dosen A)

$V_{2}=\frac{D_{2}^{-}}{D_{2}^{-}+D_{2}^{+}}=\frac{1,6894}{1,6894+3,4254}=0,3303 \rightarrow$

Alternatif 2 (Dosen B)

$V_{3}=\frac{D_{3}^{-}}{D_{3}^{-}+D_{3}^{+}}=\frac{3,1574}{3,1574+2,3080}=0,5777 \rightarrow$

Alternatif 3 (Dosen C)

$V_{4}=\frac{D_{4}^{-}}{D_{4}^{-}+D_{4}^{+}}=\frac{4,3947}{4,3947+1,5922}=0,7340 \rightarrow$

Alternatif 4 (Dosen D)

$V_{5}=\frac{D_{5}^{-}}{D_{5}^{-}+D_{5}^{+}}=\frac{2,3208}{2,3208+3,7519}=0,3822 \rightarrow$

Alternatif 5 (Dosen E)

Dapat ditampilkan hasil perhitungan SPK dengan algoritma TOPSIS pada tabel 4 .

Tabel 4. Hasil perhitungan TOPSIS

\begin{tabular}{cc}
\hline Alternatif & Hasil \\
\hline Alternatif 1 = Dosen A & 0 \\
Alternatif 2 = Dosen B & 0,3303 \\
Alternatif 5 = Dosen E & 0,3822 \\
Alternatif 3 = Dosen C & 0,5777 \\
Alternatif 4 = Dosen D & 0,7340 \\
\hline
\end{tabular}

3. Integrasi dan pengujian sistem.

sistem Dalam tahap integrasi dan pengujian menggunakan uji perbandingan. Pengujian ini mempunyai tujuan untuk memastikan bahwa perhitungan yang dihasilkan oleh sistem sudah sesuai dengan perhitungan manual yang telah dibuat sebelumya dan layak untuk digunakan.
Hasil perhitungan pada sistem memiliki hasil yang belum terurutkan seperti tertera pada gambar 8. Namun hasil perhitungan sistem tersebut akan diurutkan dan dibulatkan sesuai perhitungan manual. Berikut hasil perhitungan sistem yang telah diurutkan dan dibulatkan terdapat pada tabel 5.

\section{Tabel V(hasil)}

\begin{tabular}{|l|c|}
\hline \multicolumn{1}{|c|}{ Dosen } & D+ \\
\hline Drs. Sujono, M.T. & 0 \\
\hline Drs. Fx. Budi Raharjo & 0.33029760564295 \\
\hline Prof. Dr. Tri Atmadji S., M.Pd. & 0.57771501089104 \\
\hline Drs. Wahyu Sakti G.I., M.Kom. & 0.7340476560617 \\
\hline H. M. Rodhi Faiz, S.T., M.T. & 0.38217036798207 \\
\hline
\end{tabular}

Gambar 8. Hasil perhitungan oleh sistem

Tabel 5. Hasil perhitungan oleh sistem yang telah diurutkan

\begin{tabular}{|c|c|}
\hline Alternatif & Hasil \\
\hline Drs. Sujono, M.T. & 0 \\
\hline Drs. Fx. Budi Raharjo & 0,3303 \\
\hline H. M. Roghi Faiz, S.T. M.T. & 0,3822 \\
\hline Prof. Dr. Tri Atmadji S., M.Pd & 0,5777 \\
\hline $\begin{array}{l}\text { Drs. Wahyu Sakti G.I, } \\
\text { M.Kom. }\end{array}$ & 0,7340 \\
\hline
\end{tabular}

Setelah hasil perhitungan sistem telah diurutkan dan dibulatkan seperti pada tabel 5 . Selanjutnya tabel 4 dan tabel 5 dibandingkan dan hasilnya adalah antara perhitungan manual dan perhitungan sistem sesuai.

\section{Pengoperasian dan perawatan.}

Pada tahap ini mencakup koreksi dari berbagai bug dan error yang tidak ditemukan pada tahapan sebelumnya. Pemeliharaan dilakukan karena sistem akan terus berkembang dan dinamis sesuai dengan kebutuhan user. 


\section{PENUTUP}

Berdasarkan hasil penelitian di bab sebelumnya dapat ditarik dua kesimpulan. Kesimpulan pertama dapat mengimplementasikan algoritma TOPSIS pada sistem pendukung keputusan pemilihan dosen pembimbing skripsi. Kesimpulan kedua hasil penghitungan sistem pendukung keputusan pemilihan dosen pembimbing skripsi telah sesuai dengan hasil perhitungan secara manual.

Sistem pendukung keputusan pemilihan dosen pembimbing skripsi menggunakan algoritma TOPSIS masih dapat dikembangkan. Pertama diharapkan sistem dapat dikembangkan lebih luas lagi, tidak hanya pemilihan dosen di lingkup program studi tetapi pada lingkungan jurusan juga. Kedua sistem dapat diintegrasikan dengan sistem yang lain seperti sistem pengelompokan judul skripsi, sistem informasi tentang pengelolaan judul skripsi dan sebagainya..

\section{UCAPAN TERIMAKASIH}

Ucapan terimakasih disampaikan kepada Bapak Syaad Patmantara dan Bapak Aji Prasetya Wibawa yang telah bersedia memberikan bimbingan dan dukungan kepada penulis.Semoga Allah SWT senantiasa membalas kebaikan yang telah diberikan kepada penulis. Semoga penelitian ini dapat bermanfaat kepada para pembaca

\section{DAFTAR PUSTAKA}

Pressman, Roger S. (2012). Rekayasa Perangkat Lunak Edisi 7 Buku 1(terjemahan). Yogyakarta: ANDI.

Rosa, Shalahudin.(2013). Rekayasa Perangkat Lunak. Bandung: INFORMATIKA.

Sommerville, I. (2011). Software Engineering $9^{\text {th }}$. Boston: Pearson Education.

Munandar, Tito Aris. (2014). Sistem Pendukung Keputusan Pemilihan Siswa Kelas Unggulan pada SMA Negeri 1 Sei Rampah Menggunakan Metode TOPSIS. Pelita Informatika Budi Darma, 6(2), diterima dari http://jip.polinema.ac.id. pada Sistem Reservasi Hotel Bebasis Website dan Dekstop. Jurnal Sistem Informasi, 6 (2), 113-126, diterima dari http://jutisi.maranatha.edu

Edi, D. dan Betshani, S. 2009, Analisis Data dengan Menggunakan ERD dan Model Konseptual Data Warehouse. Jurnal Informatika, 5 (1), 71-85, diterima dari http://repository.maranatha.edu

Adelia, A. \& Setiawan, J. 2011. Implementasi

Customer Relationship Management (CRM) 